\title{
DRAGOSTEA CA DORINȚA DE POSESIUNE INTELECTUALĂ ÎN PROZA NARATIVĂ A LUI ANTON HOLBAN
}

\begin{abstract}
Teodorowicz Justyna, Dragostea ca dorinta de posesiune intelectuală in proza narativã a lui Anton Holban [Love as a desire for intellectual possession in Anton Holban's narrative prose]. Studia Romanica Posnaniensia, Adam Mickiewicz University Press, Poznań, vol. XXXI: 2004, pp. 97 109. ISBN 83-232-1353-4, ISSN 0137-2475.
\end{abstract}

The article discusses the problem of love perceived as a desire for intellectual possession of the woman in Anton Holban's narrative prose. Erotic relationship is maintained in the domain of psychological casuistry. The protagonist appears as an immature intellectual, obsessed with unravelling the woman's mystery that remains impenetrable. What he desires is not the woman, but the knowledge and the control of her intimate life. Thus, the tension of Holban's novels does not result from emotion, but from excessive rationality.

Literatura lui Anton Holban oscilează, în mare parte, în jurul tematicii erotice. Romanele $O$ moarte care nu dovedeşte nimic, Ioana şi Jocurile Daniei sînt nişte jurnale care reconstituie istoriile a trei iubiri. Totuşi, în fiecare dintre ele, dragostea este supusă rațiunii. Protagonistul-narator, dornic să-şi explice întreaga complexitate a sentimentelor sale şi ale femeii, analizează în mod excesiv fiecare gest şi fiecare cuvînt, ceea ce anihilează forța pasiunii. În consecință, iubirea nu poate să atingă o intensitate adevărată, întrucît eroul, obsedat de căutarea adevărului, nu-şi permite să trăiască o pasiune care să ducă la uitarea de sine.

În cele mai multe cazuri, femeia este privită de către eroul holbanian cu orgoliu intelectual, relaţia erotică menținîndu-se în domeniul cazuisticii psihologice. Această idee a superiorități față de parteneră este efectul totalitătii reprezentărilor conştiente ale bărbatului despre sine însuşi, adică, conform expresiei Silviei Urdea, mitului personal ${ }^{1}$. Substratul psihologic al acestui mit este rezultatul prelungirii şi perenităţii psihismului adolescentin. Acesta predomină în $O$ moarte care $n u$ dovedeşte nimic şi Ioana. Abia în Jocurile Daniei eroul se eliberează de mentalitatea adolescentinð.

' Cf. S. Urdea, Anton Holban sau interogatia ca destin, Editura Minerva, București, 1983, p. 58. 
Înainte de a analiza rolul pe care îl joacă psihismul adolescentin în relațiile protagonistului cu partenerele lui, trebuie să precizăm ce înțelegem prin acest psihism. Utilă ni se pare definiția vîrstei adolescentine formulată de către Alberta Labuda. După autoare, una din trăsăturile psihologice dominante ale acestei vîrste este egotismul care succede la egocentrismului naiv al copilăriei şi antici-pează obiectivismul adultului. Mentalitatea adolescentină opune realității sensibile o realitate a ideilor, deseori dogmatică şi intolerantă. Cît priveşte domeniul sentimentelor şi intelectului, predomină senzaţia neliniştii, labilitatea stărilor afective, susceptibilitatea aproape maladivă şi, deseori, căutarea solitudinii, ceea ce duce, în numeroase cazuri, la o apreciere nemăsurată de sine ${ }^{2}$.

Protagonistul holbanian ni se pare înrudit cu familia psiho-spirituală a „eternilor adolescenți". Relațiile pe care Sandu le va angaja cu Irina şi Ioana vor fi determinate, în primul rînd, de propria-i imagine în comparație cu care siluetele celorlalte personaje apar, în general, diminuate.

În $O$ moarte care nu dovedeşte nimic Sandu vrea să manifeste tot timpul o copleşitoare profunzime sufletească faţă de Irina. La începutul legăturii lor fata i se pare foarte atrăgătoare, dar o dată introdusă în cîmpul magic al personalitătii protagonistului devine obiectul unor numeroase umilințe: „Parerile asupra ei mi se schimbaseră mult. $\mathrm{O}$ priveam cu un aer de uşoară superioritate. Nu mai eram impresionat de vreun aspect de-al ei" ${ }^{3}$.

La fiecare pas Sandu subliniază inferioritatea Irinei. Eroina este caracterizată

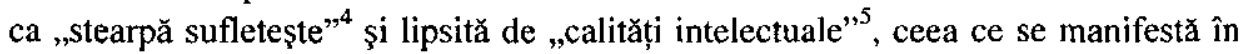
scrisorile ei: „scria la întîmplare, făă virgule şi puncte (o ironizam mai tîrziu că scrie genre Mallarmé), înseilînd laolaltă tot felul de idei care-i alergau prin cap" ${ }^{16}$. Romanul nu abundă în portrete fizice ale Irinei, şi dacă găsim vreunul, el este cu totul subiectiv şi disprețuitor.

Sandu este nemulțumit de opacitatea amantei lui în fața emoțiilor estetice elevate. Comportamentul Irinei, opiniile ei arată, după el, lipsa de gust a iubitei. Mai ales admiraţia ei fał̧ă de talentul lui de pianist, pe care el însuşi îl socoteşte mediocru, provoacă indignarea lui:

(...) Irina spunea despre mine, ca şi despre tołi cei care îi erau simpatici: „Sandu cîntă drăgut la piano!" Dupð atîtea cărţi citite şi comentate împreună, se mulţumea cu astfel de formulări rudimentare, care nu însemnau nimic şi care demonstrau nepriceperea ei complectă ${ }^{7}$.

${ }^{2}$ Cf. A. Labuda, Les thèmes de l'adolescence dans l'cuuvre d'André Gide, vol. 1, PWN, Poznań, 1968, p. 21-22 şi $51-52$.

${ }^{3}$ O moarte care nu dovedeşte nimic, Romane, I, Editura Minerva, Bucureşti, 1982, p. 12.

${ }^{4}$ lbidem, p. 39.

${ }^{5}$ Ibidem, p. 44.

${ }^{6}$ Ibidem, p. 14.

${ }^{7}$ Ibidem, p. 21. 
Eroul manifestă chiar porniri sadice față de Irina: „suferea toate toanele mele. $O$ pedepseam amarnic de orice mi se întîmpla, o umileam, o disprețuiam. Găseam cuvinte savant combinate care s-o doară"8.

Compania Irinei este prezentată de Sandu ca un fel de rău necesar, deşi fata nu dorește decît să i se dăruiască. Petrecîndu-şi timpul cu ea, Sandu se plînge de tinerețea lui pierdută:

(...) dînsa mereu îndrăgostită, iar eu din cînd în cînd dorind-o, iar restul timpului petrecîndu-1 cu ea, uneori din afecţie, alteori din milă sau din plictiseală și mereu cu impresia că-mi sacrific tineretea în mod neinteresant ${ }^{9}$.

Mai ales ideea căsătoriei cu Irina îl înspăimîntă; prin urmare, este extrem de răutăcios fał̧ă de iubită, cînd vine vorba de subiectul respectiv: „Într-o zi vorbeam, bătîndu-mi joc de fetele bătrîne şi, ca s-o chinui, am adăugat, fără vreo schimbare a vocii (...): «Tu ai sã rămîi fată bătrînă!)" "10.

Sandu nu înțelege cum a putut s-o aleagă tocmai pe Irina, ea fiind atît de diferită de el însuși. Jatã cum se manifestã aceste divergențe:

Mă mir că am putut crede în oarccare asemănări dintre noi. Irina era vorbareță, spunea la întîmplare tot ce auzea, tot ce credea momentan, dar timp de ani, cît am fost împreună, numi amintesc s-o fi auzit vreodată fâcînd vreo reflexie asupra muzicii. Doar uneori o vorbă banală şi proastă, pe care o zicea identic şi cu aceleaşi intenții: „E un băiat foarte drăgut!” şi apoi „cîntă drăgut la piano!” înlocuit cîteodată prin „vorbeşte drăgut franfuzește!"11

După opinia noastră, eroul nu-şi dă seama că tocmai din cauza acestor diferențe de intelect şi de caracter a ales-o pe Irina. După cum vom vedea mai tîrziu, naratorul holbanian se serveşte de femeie ca de oglindă pentru a-şi reflecta în ea propria personalitate.

Psihismul adolescentin al éroului se exprimã şi în dorinţa obsesională de a transforma personalitatea femeii după propriul lui gust. Prin urmare, femeia apare ca o ființă supusă bărbatului, în ceea ce priveşte dezvoltarea ei sufletească. Naratorul holbanian vorbeşte deseori de influența pe care o exercită asupra Irinei: „Cå în preajma mea şi-a îmbogătit mintea, asta e adevărat" ${ }^{12}$. De asemenea, în romanul loana Sandu îi prezintă protagonistei un coleg de-al lui, găsindu-1 inteligent şi capabil ,să o învețe o mulțime de lucruri şi să aibă o înrîurire asupra ei, punînd puţină ordine într-o minte aşa de chinuită"' ${ }^{\prime 3}$. Personalitatea femeii este deci, după părerea eroului, „amorfă”, nedepinzînd decît de acţiunea binefăcătoare a personalității puternice a bărbatului.

\footnotetext{
${ }^{8}$ Ibidem, p. 20.

${ }^{9}$ Ibidem, p. 46.

${ }^{10}$ Ibidem, p. 23.

${ }^{11}$ Ibidem, p. 42.

${ }^{12}$ Ibidem, p. 59.

${ }^{13}$ Ioana, Romane, I, p. 138.
} 
Opera lui Anton Holban este pătrunsă de ideea neputinței dezvăluirii misterului feminin. Eroinele apar ca nişte „,prezențe fugitive”, adică insesizabile. Problema cunoaşterii ființei iubite devine capitală, întrucît în momentul în care începe iubirea, amanții nu se cunosc. Lucrul este posibil, fiindcă - cum vom vedea mai tîrziu dorința are caracterul impersonal şi se ataşează deseori la persoane întîmplătoare.

În domeniul iubirii, scopul naratorului este cel de a "penetra" atenţia femeii, de a o ,poseda” în sens psihic. Sandu găsește plắcere nu atît apropiindu-se de femeie, cît observînd plăcerea pe care el i-o oferă femeii. Astfel, iubirea poate fí percepută ca o luptă între două personalităţi indiferente. Adevărata ,prezență fugitivă" este aici cea a bărbatului; ținta lui este atinsă în momentul cînd femeia se apropie de el şi atunci $e l$ poate să se retragă şi să observe interesul ei cu o indiferență liniştită. Un exemplu al acestui joc dintre bărbat şi femeie ne este oferit în romanul $O$ moarte care nu dovedeşte nimic. La început Irina, privită de la distanţă, îl interesează pe Sandu, dar o dată ce el îşi dă seama că este obiectul sentimentelor ei, devine indiferent. Iubind, Irina devine victimă, întrucît se plasează în interiorul relației. Sandu, rămînînd în exteriorul ei, este invulnerabil atîta vreme cît îşi exercită în deplină siguranță dominația.

Emoțiile trăite de eroul holbanian au, aşadar, un caracter impersonal. Sandu se dovedeşte nu sentimental, ci lucid. Ținta lui este aceasta de a descoperi adevărul, de a căpăta certitudine asupra oricărui aspect al vieții, atunci şi asupra dragostei, întruchipată în partenerele ei:

Aud respiraf̧ia Irinei, nu ştiu numai dacă aceasta va fi Irina adevărată, şi asta aş vrea s-o ştiu. Si mercu încep cercctările mele de la capăt, cercetări zadarnice, care nu vor duce la nici un rezultat, dar la care nu am tăria să renun! ${ }^{14}$.

Ceea ce dorește naratorul holbanian, este o imagine clară şi unică a iubitei. Anevoie acceptă faptul că Irina este schimbătoare, că comportamentul ei este uneori contradictoriu. Cercetarea continuă ca antidot pentru o viață insesizabilă devine totuşi ineficace: în loc de o imagine clară a lumii înconjurătoare, protagonistul obține o mulțime de perspective, ceea ce aduce fragmentarism şi incertitudine. Sandu se mişcă în acest cerc vicios, ajungînd la o impresie de absurd. „Cu cît mă gîndesc mai mult, cu atît se muitiplică detaliile şi văd mai puțin clar" ", constată eroul. Observăm la el un sistem de motivații multiple, care se manifestă prin folosirea întrebărilor neterminate şi a frazelor de tip „fie... fie...”, pentru a explica comportamentul altora. lată un exemplu de bănuieli ale lui Sandu:

A fost în stare (...) să intre în cinematograful acela? Din spirit de bravare sau de inconştienţă. Sau pentru că o impresionase prea mult.gestul de a se duce la un cinematograf de cartier şi nu putuse renunţa la el. Sau poate că s-a dus la alt cinematograf. Sau o fi impins curajul şi mai mult, ca tovarăşii săi să nu bănuiască nimic, sau să se arăte slabă în faţa lor şi-o fi intrat

\footnotetext{
${ }^{14}$ O moarte care $\mathrm{mu}$ dovedeşte nimic, p. 28.

${ }^{15}$ Ibidem, p. 9.
} 
într-un cafeu cît de cunoscut? Sau într-o cafenea obscură, ca să n-o vadã cineva, pentru că savurează lucrurile umile, deprinsă cu gîndul cinematografului umil la care trebuia să mearga ${ }^{16}$.

Tocmai acest sistem de explicaţii posibile multiple şi mai ales trecerea de la o imagine mentală dureroasă la alta ilustrează cum dorința de a percepe unele fapte duce la proliferarea ipotezelor care fac realitatea exterioară şi mai impalpabilă. Sandu este conştient atît de imposibilitatea sesizării naturii Irinei, cît şi de cauza acestei imposibilități, care constă în multiplicarea perspectivelor:

Sînt în romane anumite füiņe insesizabile din pricina unui mister voit, aruncat asupra lor de autor, a unor detalii neexplicate, a unor evenimente neaşteptate, a unor vorbe stranii. (...) Eroina mea e insesizabilă dintr-un motiv contrar: truda mea de a o explica în întregime şi de a arunca asupra ei toată lumina de care sînt în stare ${ }^{17}$.

Urgența de a şti, inseparabilă de gelozie, paralizează atunci capacitatea pragmatică care caracterizează de obicei atenția acordată de noi lumii; Sandu, fiind extrem de atent, este totodată şi extrem de credul.

Trebuie subliniat că, în opera scriitorului român nu găsim imaginea genuină a atracției erotice. Iubirea fizică este rareori o sursă de plăcere în $O$ moarte care $n u$ dovedeşte nimic. Ceea ce doreşte protagonistul, este nu Irina, ci mai degrabă cunoaşterea şi controlul dorințelor ei. Sandu ar vrea să posede conştiința Irinei, căci ocupînd complet atenţia ei, găseşte o dovadă vizibilă a propriei sale existenţe. Aşadar, eroul vrea mai mult decît posesiunea fizică, dar posesiunea fizică este un mijloc de a căpăta ceea ce el doreşte cu adevărat. Tocmai prin intermediul sexualității Sandu o posedă sau o pierde pe Irina. Este gelos pe ea fără a o dori în fond. Protagonistul inițiază actul sexual din nevoia urgentă a răzbunării, fiind gelos pe nunta la care Irina s-a amuzat fáră el. Se simte deseori plictisit, chiar în momentele cele mai intime: „nimic nu mă mai tenta, cu tot trupul fraged şi gol de lîngă mine" ${ }^{\prime 18}$, declară Sandu.

Este demn de observat că în opera holbaniană verbul „,a şti” apare mult mai des decît verbul ,a iubi”. Plācerile şi bucuriile eroului sînt rezultatul descoperirii adevărului, ci nu efluviilor lirice.

Dragostea, percepută ca dorinţa de posesiune intelectuală, se naşte în proza holbaniană din sentimentul neliniştii neprecise, forță care nu se aplică încă la un obiect determinat. Este vorba de dorința față de o femeie care trece, față de o necunoscutã; mai general - față de mister. În acest fel Sandu este atras de grupul fetelor tinere printre care se află Irina, şi care par „,intangibile” lui Sandu. Ele sînt „mereu împreună, fără amestec printre ceilalţi, vioaie, grăbite, surîzătoare, (...) distante, 19 . Viața fetelor fiind plină de secrete în ochii eroului, dorinţa lui cea mai

\footnotetext{
${ }^{16}$ Jocurile Daniei, Romane, II, p. 144.

${ }^{17}$ O moarte care nu dovedeşte nimic, p. 62.

${ }^{18}$ Ibidem, p. 22.

${ }^{19}$ Ibidem, p. 10.
} 
urgentă este de a face cunoştinţă cu ființele misterioase. Pentru Sandu un asemenea act ar confirma propriile lui calităti. „Cunoştința lor”, mărturiseşte eroul holbanian, „ar fi o dovadă a importanţei mele",20. Este semnificativ faptul că Sandu le doreşte pe toate fetele, neştiind nimic despre vreuna dintre ele. Dorința protagonistului apare deci ca o forță disponibilă, căutînd un obiect asupra căruia s-ar putea exercita. Sandu este îndrăgostit fără să ştie de cine. Trebuie aleasă acum o actriţă căreia îi va fi atribuit rolul femeii iubite. Totuşi, dorința eroului fiind oarbă din cauza avidității lui, alegerea acestei ființe nu se poate face în funcție de calitățile ei, ci întîmplător; mai ales pentru că o anumită persoană se află în preajmă într-un moment potrivit şi - lucru important - pentru că este nepăsātoare. Aşa este ,aleasă” Irina. Dacă Sandu crede că femeia participa la o viață necunoscută în care dragostea ei l-ar admite şi pe el, aceasta este suficient ca să se nască iubirea. Sentimentul va fi cu atît mai viu, cu cît misterul femeii este mai mare. „Neputința de a o avea în voia mea îmi îmboldea dorinţele",21, mărturiseşte eroul holbanian. Aşadar, femeia pare atrăgătoare, fiindcă este inaccesibilă, fiindcă are dorinţe misterioase. $O$ dată ce bărbatul se simte obiectul acestor dorințe, senzația lui de taină, şi totodată interesul lui tind să dispară. După ce vălul misterului pare înlăturat în decursul vieţii comune, Sandu se simte dezamăgit. Irina devine curînd „fadă” în ochii lui. S-ar putea presupune, atunci, că forța sentimentului suscitat de dorință sau aprehensiune nu poate rezista nici la posesiune, nici la descoperirea neantului în loc de ceea ce eroul a judecat atît de favorabil. Aici, totuşi, intervine o lege care spune că iubirea se renaşte brusc dacă apare o umbră de îndoială. Dragostea apare deci ca o suită interminabilă de certitudine - legată de plictiseală, şi incertitudine - legată de suferință. Aşa este istoria iubirii lui Sandu pentru Irina. După atîtea gînduri la o libertate fáră ea, tăcerea ei de cîteva zile declanşează în Sandu, plecat la Paris, o suferinţă de proporții inimaginabile: „De atîtea ori m-am gîndit s-o termin cu ea, şi acum i-am scris să vie neapărat, că fac tot ce va spune",22.

O asemenea atitudine este o dovadă a iubirii nemărginite sau - mai degrabă a geloziei nestăpînite? lată răspunsul eroului însuşi:

De fapt, mă doare mai putin supozitja dragostei ei netrainice decît gelozia că va aparţine altuia. Că va fi îmbrăţişată pe gură, pe tot corpul gol, că va fi a lui, că ea, după cîteva săptămîni (poate mai puţin) de primire servilă a mîngîierilor - obligată fałă de amintirea de altădată - după cîteva lacrimi de remuşcare, simţind că totuşi faptul brutal produce asupra simfurilor ei, acum învătate, aceeaşi voluptate, va lăsa slobodă firea ei, se va încolătăci, va tremura, va geme, va obosi ${ }^{23}$.

Gelozia este o fortă torturantă şi inevitabilă. Nu-1 părăseşte pe erou niciodată, chiar dacă a trecut mult timp de la evenimentele dureroase, chiar dacă iubita este moarta.

\footnotetext{
${ }^{20}$ Ibidem, p. 10.

${ }^{21}$ Ibidem, p. 21.

${ }^{22}$ Ibidem, p. 85.

${ }^{23}$ Ibidem, p. 73.
} 
Strict legată de ideea dragostei ca dorinta de posesiune intelectuală este problema prezenței şi absentei femeii. Pe de o parte, eroul se simte deseori obosit de prezenţa ei continuă. Astfel, Sandu o încurajează pe Irina să-l părăsească: „, povăţuiam să aibă voința să mă uite și să se distreze cu alțiij" ${ }^{24}$. Pe de alta, cînd pierde controlul asupra activităţilor Irinei, imediat devine gelos pentru clipele petrecute de ea în altă parte: „m-a durut mai ales petrecerea la care se amuzase fără mine"25. De asemenea, cînd familia ei are đe gînd s-o căsătorească cu altcineva, Sandu nu se împotriveşte, totuşi este mulţumit de întoarcerea lrinei:

Cînd mi-a spus Irina, rîzînd, istoria, am trimes-o să-l vadă şi, dacă se poate, să-l accepte. La întoarcere mi-a povestit toată prostia candidatului şi eu m-am amuzat cel dintîi. (Am trimiso ca să încerc să găsesc o modalitate de a scăpa de ea, în acelaşi timp, să-i văd repulsia față de alții şi întoarcerca ei și mai nebună spre mine. $)^{26}$

Romanul Ioana este aproape în întregime o înregistrare a geloziei naratorului pentru timpul cînd partenera lui a trăit cu „celălalt” şi cînd el nu o putea supraveghea. În Jocurile Daniei, de asemenea, găsim nenumărate întrebări lăsate în cele mai multe cazuri fără răspuns, privitoare la călătoriile iubitei la care el nu poate participa. Sandu repetă:

Ce făcea ea în momentul acela (...)? La un teatru? La un ccai? Invitată? (...) Să poți asista, cum numai la cinematograf se poate face, la două scene aproape în acelaşi timp" ${ }^{\text {"27 }}$.

Şi ̂̂i reproşează Daniei că ,nu spune nimic despre viața ei trecută ${ }^{, 28}$.

După cum am observat mai sus, faptul de a fi gelos pentru clipele petrecute de iubită în alte locuri, necunoscute eroului, nu înseamnă dorintă de prezența permanentă a frmeii. Sandu prețuieşte deosebit singurătatea ca sursă a experiențelor unice. În romanul Ioana, cu prilejul unei excursii, fáră parteneră, la Braşov, protagonistul se bucură de libertate şi descoperă că numai ,în singurătate şi în tăcere se pot trăi clipele într-adevăr profunde" ${ }^{, 29}$. Asemenea clipe sînt oferite eroului holbanian şi de ascultarea muzicii în care el găseşte „singurele consolări”, „,Eu profitam de muzică - mărturisește Sandu - pentru că mă puteam retrage în mine, pentru a nu mi se mai părea cã ceea ce-mi este mai intim a fost invadat de un străin”31. Adaugă totuşi că decorul în care trebuie ascultată muzica este tocmai singurătatea.

Sandu doreşte, deci, ca femeia să fie întotdeauna la dispoziţia lui, dar ca să nu-1 obosească cu prezența sa. Preferabilă este absența temporară a iubitei, totuşi însoțită de certitudinea revenirii ei. Abia în asemenea clipe, cînd eroul holbanian este

\footnotetext{
${ }^{24}$ Ibidem, p. 22.

${ }^{25}$ Ibidem, p. 16.

${ }^{26}$ Ibidem, p. 22.

${ }^{27}$ Jocurile Daniei, p. 21.

${ }^{28}$ Ibidem, p. 36.

${ }^{29}$ loana, p. 195.

${ }^{30}$ Ibidem, p. 157.

${ }^{31}$ Jbidem, p. 157.
} 
singur, dar şi sigur de ocupațiile iubitei, poate fi liniştit. Astfel, Sandu exprimă convingerea că pentru dezvoltarea vieţii lui sufleteşti este favorabilă o prezenţă episodică şi atunci liniştitoare a femeii. Această stare de prezență parțială Mihai Zamfir o numeşte semi-absența $\check{a}^{32}$. Ea se realizează prin intermediul unor mijloace de comunicare precum scrisori, mesaje trimise prin terți şi convorbiri telefonice, care întreţin şi prelungesc întîlniri reale.

O bună ilustrare a psihologiei semi-absenței ne-o oferă romanele $O$ moarte care nu dovedeşte nimic şi Jocurile Daniei. Primul începe cu semnificativa scenă a plecării eroului la Paris. Călătoria aceasta fiind împlinirea viselor lui încă din copilărie, Sandu este excitat şi fericit. Despărţirea lui de Irina este stîngace: „acum nu ştiam ce să-i vorbesc" ${ }^{\text {,33 }}$, mărturiseşte naratorul. Sosit la Paris, se mulțumeşte cu scrisorile frecvente ale iubitei, adevărata lui plăcere fiind atracțiile oferite de capitala Franței:

Trăiesc din surprize, şi seara adorm istovit de atita goană prin muzee şi pe strãzi. De la Irina îmi vin scrisorile la dată fixă, aşa cum hotãrîsem acasă. î̉ răspund conştiincios, dar grăbit, cu gîndul în altă parte, vorbindu-i de lucruri care probabil n-o interescazł. (...) Despre mine și despre dînsa nimic, doar un „dragă” la început şi „sărutări” la urmă ă $^{34}$.

Sandu, fiind conştient de răceala lui față de Irina, face o observaţie lucidă: „Aşa îşi scriu îndrăgostiţii şi acestea sînt mijloacele de a întreţine focul nestins?"35 Greșeşte însă, crezînd că indiferenţa lui este deplină, că dorește să se elibereze de Irina, întrucît faptul de a nu primi la timp veşti de la parteneră este suficient ca o nelinişte bruscă să se nască în el şi ca descoperirea motivului tăcerii Irinei să devinā singura lui preocupare. Ceea ce Sandu doreşte într-adevăr, este tocmai absența Irinei controlată de el, adică semi-absența.

Jocurile Daniei este o reprezentare şi mai ilustrativă a stării semi-absențej, întrucît comunicarea între amanţi se realizează aproape exclusiv prin convorbiri telefonice care constituie un fel de schemă narativă a textului. Alexandru Protopopescu numeşte chiar Jocurile Daniei ,un roman despre telefon" ${ }^{, 36}$. De fapt, sînt foarte puține pagini în roman în care cuvîntul ,telefon" $n u$ apare. Iată unul dintre fragmentele cele mai reprezentative pentru importanța conversațiilor la telefon:

Intîlnirile noastre obicinuite de la casa ci se petrec cam la fel. Mai intîi, la telefon: „lubite, vrei sã vii la mine?” Mă întreabă după o ezitare. Răspund: „Da? În cît timp? Într-o oră?” "Mai curînd, cît mai curînd posibil". (...) Ajungeam cit puteam mai repede. (...) Dar aveam

${ }^{32}$ Cf. M. Zamfir, Structura semi-absentei, în Viała românească, XXXV (1982), nr. 8 (august), p. 30 .

${ }^{33}$ O moarte care nu dovedeşte nimic, p. 7.

${ }^{34}$ lbidem, p. 7-8.

${ }^{35}$ Ibidem, p. 8.

${ }^{36}$ A. Protopopescu, Romanul psihologic românesc, Editura Eminescu, Seria „Sinteze”. București 1978, p. 180. 
mult de aşteptat, aproape o jumătate de oră. (...) În sfîrşit, sosea. Se scuza convențional de întîrziere. Dar nu-i fáceam nici o obiectie, era inutil. (...) Numai acceptînd gesturile Daniei ca naturale nu eram umilit. Începea conversaţia noastră stîngaci, Dania nu mai păstra nimic din febrilitatea cu care mă chemase la telefon. (...) Dania nu mă întreba ce făcusem de cînd nu mă văzuse. Dar nu spunea nimic nici despre dînsa, ca şi cum n-aş fi avut nici un drept asupra vieții ei de fiecare zi. Eu nu întrebam, căci mă jignea tăcerea ei. Sau, cînd întrebam, îmi răspundea ceva atît de ciudat, fâră de nici o legătură cu închipuirile mele, încît renuntam sả continui ${ }^{37}$.

Se vede cu uşurință că întîlnirile ,reale" dintre Sandu şi Dania sînt convenționale şi, în consecință, reci. Naratorul, dezamāgit de superficialitatea mondenă a partenerei în clipele petrecute împreună, o numeşte deseori „o minunată pāpuşă ${ }^{38}$. Aşadar, semi-absența acesteia devine benefică, întrucît numai în condițiile comunicării la distanță Dania se angajează emoțional. Cum observă Sandu, „cuvintele cele mai pasionate [sînt] spuse numai la telefon" ${ }^{\text {"39 }}$. Avem atunci de a face cu două personaje diferite: Dania cea indiferentă şi Dania - proiecţie a viselor eroului, care este atributul exclusiv al stării de semi-absență.

Al doilea tip de scene tipice pentru psihologia semi-absenței în romanul Jocurile Daniei îl reprezintă aşteptarea scrisorilor femeii iubite. Iată cum eroul descrie situația după prima absență lungă a Daniei:

După cîteva zile, cînd fácusem socoteala că trebuie să-mi scrie, m-am dus fără de nici o bănuială, surîzător de succesul meu sigur, la cutia de scrisori. Apoi la factorul următor şi la al treilea. Am început să-mi dau singur explicaţii: poate că numărasem eu greşit. Să cerem informații. Din prima zi nu-mi scrie, sînt prea pretențios. Poate că nu mi-a reţinut bine adresa. Sau s-a pierdut scrisoarea... Sau... Nu înţclegeam. (...) Mady a spus: „, ş̧a e ea!” Cum aşa? Adič̆ este inutil să aştept un semn? În fiecare zi, inutil? Voi vedea factorul venind și nu-i voi ieși în întîmpinare? ${ }^{40}$

Fragmentul de mai sus demonstrează că absența iubitei nu este în sine o sursă a tragediei sentimentale a eroului. Prima frază - să amintim că Sandu este „surìzător” şi sigur de succes - descrie speranța instalării relaţiei perfecte, cea provocată de starea semi-absenței. Scrisoarea, dacă ar veni, ar oferi naratorului iluzia relației permanente. Dezamăgirea începe cînd semi-absența devine imposibilă din cauza tắcerii Daniei.

Semi-absența, fiind efectul eforturilor multiple ale eroului (întrucît tocmai el provoacă în cele mai multe cazuri convorbiri telefonice cu iubita), este o stare temporară care se termină inevitabil cînd lipsesc semnele care o constituie. Aventura erotică cu Dania se încheie o dată cu încetarea corespondenței dintre ea şi Sandu. Acesta hotărăşte să se odihnească în casa bunicilor, într-un mic oraş de

\footnotetext{
${ }^{37}$ Jocurile Daniei, p. 39.

${ }^{38}$ Ibidem, p. 31.

${ }^{39}$ Ibidem, p. 132.

${ }^{40}$ Ibidem, p. 21.
} 
provincie. Semi-absența partenerei capricioase îi este indispensabilă pentru realizarea scopurilor lui intelectuale:

Febrilitatea în care trăisem devenise insuportabilă. În atmosfera aceasta mă refac. (...) Voi scrie, voi citi, cărţile pot fi oricît de mari, oricît de complicate. Voi putea aici să redevin omul muncitor de odinioară, ambitios să-şi inmulțeasç ştiinta ${ }^{41}$.

Totuşi, nu poate lucra liniştit, întrucît îi trebuie şi scrisorile Daniei pe care le aşteaptă nerăbdător:

Factorul marca existenţa mea de fiecare zi. La şapte dimineaţa mă trezeam. Pînă la opt n-aveam griji multe, dar mai pe urmå eram tot mai îngrijorat (factorul vine pe la nouă). Ieşeam din casă la fiecare minut, să mă uit înspre stradă. Mă temeam să nu vie tocmai cînd îmi iau cafeaua cu lapte (...). Veneam pînă la poartă şi mă uitam în lungul străzii. (...) Desigur, dacă n-aş fi fost de faţă, factorul ar fi putut să-mi lase scrisoarea la altcineva. Dar dacă scrisoarea s-ar fi rătăcit? (...) În sfîrşit, zăresc factorul. (...) Caut să ghicesc pe chipul factorului dacă are ceva pentru mine pe cînd traversează curtea noastră. Constat că nici nu mă bagă în seamă, că ar găsi oricînd pe altcineva căruia să-i lase corespondența. Mă mişc eu, mă ofer să fac eu serviciul acesta. De fapt, mai sper că totuşi se va găsi ceva pentru mine şi că factorul imbecil nu s-a priceput să fie mai explicit, sau că meseria i-a netezit orice expresie. Inutil, nimic pentru mine. Uneori factorul se uită în grămada de scrisori, să vadă bine dacă nu cumva mai este ceva pentru noi. Atunci aştept, chinul meu este deplin. „Nu e nimic!” Sau: „Ba da!” O scrisoare pentru altcineva. Voi trebui să aştept iarăşi o zi întreaga ${ }^{42}$.

Lungul citat de mai sus este doar un fragment al descrierii detaliate şi vaste a aşteptării zilnice. Sandu ia în considerare toate cauzele posibile ale tăcerii Daniei încercînd, zadarnic, să se consoleze. În fine, hotărăşte să n-o mai vadă pe parteneră. Restul rupturii se produce spontan.

Strict legată de problema absenței este ideea singurătății ca stare indispensabilă pentru creația literară a eroului. Sandu, respingînd ideea căsătoriei cu Irina, se foloseşte de „o teorie asupra temperamentelor artistice”, şi argumentează că „un astfel de temperament trebuia lăsat în voie şi nu trebuia înlănţuit cu obiceiuri burgheze"43.

Dorința de posesiune intelectuală se manifestă la protagonistul holbanian şi într-un fel de didacticism cultural. Cultura, în general, şi literatura, în special, devin substitutul unor sentimente inexistente, un mijloc la care protagonistul recurge pentru a-şi abate atenţia de la conflictele latente dintre el şi Irina. Cu alte cuvinte, factorul intelectual ascunde adesea absența iubirii sau indecizia erotică. În mod evident, cultura literară îndeplineşte şi funcţia de indicator al superioritạtii bărbatului care este, cum am spus la începutul prezentului articol, o manifestare a mitului personal.

\footnotetext{
${ }^{41}$ Ibidem, p. 153.

${ }^{42}$ Ibidem, p. 153-154.

${ }^{43}$ O moarte care nu dovedeşte nimic, p. 22.
} 
Toate eroinele romanelor holbaniene trăiesc, într-un fel sau altul, în umbra cunoştințelor literare ale lui Sandu. Irina, cum am observat ceva mai devreme, este privită de partener ca o persoană incultă. Eroul hotărăş̧e deci să o educe, lăsîndu-i deseori, mai ales înainte de o despărțire mai lungă, o listă de cărți și un plan de studii şi cerîndu-i apoi rezultatele. Nu este totuşi mulţumit de Irina care se dovedeşte indiferentă față de plăcerile lecturii:

Ea trebuia să-mi scrie observaţiile și nu-mi scria niciodată despre asta în fierbințeala ríndurilor pasionate sau numai oarecare, iar la întrebările mele repetate se mulţumea numai cu generalităłi (,foarte interesant” sau „nu-mi prea place”), care mă enervau. La întoarcere, constatam că nu lucrase aproape nimic, că în fiecare zi i se întîmplase cîte un accident care s-o oprească, şi că ceea ce cetise fusese în fugă, fără de nici un sistem ${ }^{44}$.

Lista lecturilor simbolizează într-un sens sentimentele care îi leagã pe cei doi amanți, se substituie acestor sentimente. Acceptarea de către Irina a planului alcătuit pentru ea de Sandu este egală cu acceptarea bărbatului însuşi. Lipsa de acceptare a listei cărților înseamnă lipsa de fidelitate. Așa o percepe eroul holbanian:

Cu toate că-i dådusem planul lecturilor, în una din ultimele scrisori, vestise: "Pentru variafie am început o carte de istorie foarte interesantă". În momentul acela mi-am presimţit toate nenorocirile. Am bănuit prezenta unui nou-venit ${ }^{45}$.

După cum s-a spus, Sandu consideră că, petrecînd ore întregi cu Irina, îşi sacrifică tinerę̦ea. Atunci, fară să se gîndească la ceea ce o interesează pe parteneră, încearcă să discute cu ea despre pictură sau literatură, discipline care îl interesau totdeauna, ,,ca să nu pierd timpul”, ${ }^{46}$, cum explică el însuşi.

Şi celelalte protagoniste sînt influențate de cultura literară a lui Sandu. Ioana este fosta lui elevă pe care tocmai el a învățat-o să citească şi să interpreteze literatura, mai ales pe cea clasică. Cît o priveşte pe Dania, ea a fácut cunoştință cu protagonistul tocmai datorită profesiei sale de scriitor. Fata a fost atrasă în mod deosebit de ideile exprimate în creaţia literară a lui Sandu şi a hotărît să se apropie de el.

În comportamentul protagonistului holbanian se pot observa cu uşurinţă tentativele desperate de a folosi literatura drept un substitut al vieţii intime. Pentru a evita subiectele inconvenabile, privitoare la sentimentele lui şi mai ales la ideea căsătoriei, atît de repulsivă pentru el, Sandu îi vorbeşte Irinei despre planurile artistice. Dacă partenera manifestã nemulțumire, el o ambiţionează: „Nu-ţi plac astfel de conversafiii? Dar înainte de toate tu eşti o intelectuală!" ${ }^{47}$ Eroul holbanian este conştient de absurditatea situației, comentînd-o în felul următor: „Ce scenă de înalt ridicol! În momentul cînd o femeie se dă cu toată carnea şi sufletul, tu să-i

\footnotetext{
44 Ibidem, p. 25.

${ }^{45}$ Ibidem, p. 88.

${ }^{46}$ Ibidem, p. 14.

${ }^{47}$ Ibidem, p. 50.
} 
vorbeşti despre Proust, «căci eşti intelectuală!» Şi ea să trebuiască să spuie: «Desigur!»"48 Sandu este artificial, jucîndu-se cu Irina de-a iubirea şi umplîndu-şi astfel golul sentimental cu o poză intelectuală.

În opera prozatorului apar numeroase nume de scriitori. Autorul cel mai des pomenit, iar uneori şi comentat este, probabil, Racine. La acest clasic Holban caută „explicarea vieții" şi încearcă să aplice principiịle descoperite în literatură la loana:

În femeile din romanele ruseşti găsesc, alături de intensitatea sentimentelor, şi capriciul cu care se produc ele. La francezi, agitația Hermionei depinde de Pirus, după un plan matematic. Agitaţia loanei $n$-are de multe ori nici un fel de explicaţie. Niciodată nu sînt sigur de ce o să producă în ea vreun gest de-al meu, aşa sînt surprizele de mari ${ }^{49}$.

Sandu confundă astfel viața reală cu lumea ficțiunii literare, atribuind acesteia din urmă rolul unui îndreptar ale cărui elemente le va aplica la propria lui viață. Pentru protagonistul holbanian, eroinele raciniene constituie nişte modele la care el doreşte să conformeze realitatea. Teatralitatea vieții sale nu-i scapă lui Sandu; eroul pare conştient de faptul că o judecă pe Irina după modelele clasice: „Şi literatura e de vină că nu ne împăcăm cu iubitele noastre. Trăim în iluzii şi realitatea apoi nu ne place" ${ }^{, 50}$. După opinia lui Sandu, Irina nu seamănă deloc cu Andromaca, aceasta din urmă fiind cinstită şi lipsită de slăbiciuni. Cel mai apreciat merit al eroinei raciniene de către naratorul holbanian este că ,rezistă fără greutate imprecațiilor lui Pirus"s1, pe cînd Irina i-a cedat lui însuşi prea repede. Urmează o comparație cu Esther care îşi riscă viața pentru salvarea neamului său şi cu Monime, ascultătoare față de hotărîrile soartei şi gata să accepte dorința impetuoasă a lui Mitridate cu toate că aceasta înseamnă renunțarea la propriile ei sentimente. Bérénice este admirată de Sandu pentru curajul ei deosebit, și Junie pentru demnitatea ei, care nu o lasã să cedeze "fără inelul de nuntă pe deget" ${ }^{\text {"2 }}$. Concluzia la care ajunge eroul holbanian sună trist: „Din pricina închipuirilor lui Racine, Irina, singura cu respirația veritabilă, mi se pare bicisnică și fadă ${ }^{, 53}$.

Comparați cu personajele literare ideale, ale căror sentimente sînt statornice şi, mai ales, uşor de clasificat, oamenii vii par imperfecți, creînd astfel frustrare. Iată cum o percepe protagonistul holbanian: „Educația noastră tîmpitā ne-a dat iluzia absolutului, şi de aceea sîntem mereu nenorociți, descoperind că orice sentiment nu este decît aproximativ" 54 . Sandu trăiește doar în lumea ficțiunii literare. Din acest punct de vedere, protagonistul seamănă cu celălalt amant al Ioanei, care nu înțelege comportamentul ei. Eroina observă: „Ce uşor pricepea unele chestiuni dificile, din

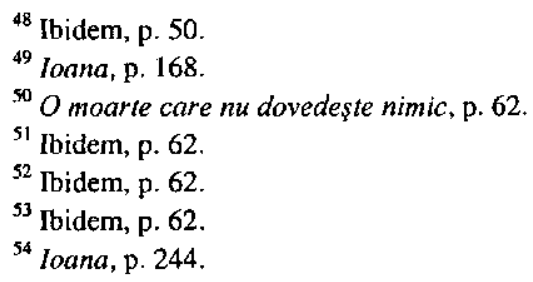


cărțile cele mai subtile, şi ce străină îi era o problemă de viață”,55. Comparată cu bărbații rupți de viață, protagonista apare ca o personalitate reală, pe care inteligența și gustul literaturii nu o închid în lumea visătoare a cărților.

Eroul romanelor holbaniene apare ca un intelectual imatur care refuză să-şi asume responsibilitățile aduse de viața reală. Obsedat de semnificația fiecărui eveniment şi a fiecărei stări sufleteşti, el se lansează în divagări teoretice pentru descifrarea eternului feminin care rămîne impenetrabil, spre dezorientarea analistului. Obiectul dorinţei protagonistului holbanian este nu atît femeia, cît cunoaşterea și controlul vieții ei intime. Aşadar, tensiunea care caracterizează romanele luj Holban nu este cea a afecțiunii, ci a lucidităţii.

\footnotetext{
${ }^{55} \mathrm{lbidem}$, p. 256.
} 